\title{
INFLUENCE OF NITROGEN AND PHOSPHORUS ON YIELD AND SEED QUALITY OF FRENCH BEAN
}

\author{
S.S.Kakon ${ }^{1}$, Md. S.U. Bhuiyan ${ }^{2}$ and S.M. A. Hossain ${ }^{2}$ \\ ${ }^{1}$ Agronomy Division, Bangladesh Agricultural Research Institute, Gazipur-1701 \\ ${ }^{2}$ Department of Agronomy, Bangladesh Agricultural University, Mymensingh-2200 \\ Corresponding author: kakonbari@gmail.com
}

Key words: French bean, pod set, yield and seed quality

\begin{abstract}
The experiment was conducted at the research field of Agronomy Division, Bangladesh Agricultural Research Institute (BARI), Joydebpur, Gazipur during Rabi (winter) season of 2010-11 to 2011-12 to determine the optimum rate of nitrogen and phosphorus fertilizer on yield and seed quality of French bean. A randomized complete block design was followed with ten treatment combinations such as $\mathrm{N}_{0} \mathrm{P}_{0}$, $\mathrm{N}_{0} \mathrm{P}_{44}, \mathrm{~N}_{50} \mathrm{P}_{44}, \mathrm{~N}_{100} \mathrm{P}_{44}, \mathrm{~N}_{150} \mathrm{P}_{44}, \mathrm{~N}_{200} \mathrm{P}_{44}, \mathrm{~N}_{150} \mathrm{P}_{0}, \mathrm{~N}_{150} \mathrm{P}_{22}, \mathrm{~N}_{150} \mathrm{P}_{33}$ and $\mathrm{N}_{150} \mathrm{P}_{55}$. Number of pods and yield of French bean were significantly increased with the increase in $N(150)$ and $P(44) \mathrm{kg} \mathrm{ha}^{-1}$. Averaged over the years, maximum number of pod $\left(9.45\right.$ plant $\left.^{-1}\right)$ and seed yield $\left(1563.33 \mathrm{~kg} \mathrm{ha}^{-1}\right)$ were obtained when $\mathrm{N}$ and $\mathrm{P}$ were applied at the rate of 150 and $44 \mathrm{~kg} \mathrm{ha}^{-1}$, respectively while lowest yield to $\mathrm{N}_{0} \mathrm{P}_{0}$ treatment in both the years. The treatment $\left(\mathrm{N}_{150} \mathrm{P}_{44} \mathrm{~kg} \mathrm{ha}^{-1}\right)$ gave the highest seed yield which was 51.4 and $54.30 \%$ higher than the control. Quality in terms of germination percentage and vigour index of harvested seed was also significantly influenced by higher doses of $\mathrm{N}$ and $\mathrm{P}$ while the lowest seed quality from plants that received no fertilizer in both the years.
\end{abstract}

\section{Introduction}

French bean (Phaseolus vulgaris L.) is a dual purpose crop grown as a pulse and vegetable crop. Its dry seeds are very nutritious containing about $24.9 \%$ protein, $60.1 \%$ carbohydrate, fat, thiamin, riboflavin, Ca, Fe and niacin as well as fibre (Pierce, 1987; Rashid, 1999 Including leguminous crop like French bean could improved cropping system as well as improve soil fertility. Recently cultivation of French bean is gaining popularity in Bangladesh because of its high nutritive value, good taste and wide range of use and also export purpose. But its yield is low compared to other French bean producing countries of the world due to lack of improved cultivars, balanced nutrition and cultural practices. Unlike other pulses, French bean is inefficient in symbiotic nitrogen fixation (Ali and Lal, 1992) as it lacks nodulation due to the absence of NOD gene regulator (Kushwaha, 1994). As nodulation is poor in french bean, it requires more $\mathrm{N}$ and $\mathrm{P}$ for root development, nodulation and better plant growth (Ssali and Keya, 1986). Phosphorus not only enhances the root growth but also promotes early plant maturity (Mullins et al., 1996). Reddy et al. (2010) also reported that increased nitrogen levels from 75 to $150 \mathrm{~kg} \mathrm{ha}^{-1}$ improved the yield attributes and seed yield $\left(520 \mathrm{~kg} \mathrm{ha}^{-1}\right)$ over $125,100,75 \mathrm{~kg} \mathrm{~N} \mathrm{ha}^{-1}$, respectively.

Padrit et al. (1996) found that phosphorus application to the seed crop of peas had improved seed vigour. Rao et al., (1983) observed that plants deficient in phosphorus produce seeds having slower germination than normal seed. French bean seed yield and quality can be enhanced by adopting improved agronomic practices, particularly by applying balanced nutrition to the crop. The present investigation was, therefore, carried out to determine the 
Kakon et al.

optimum level of nitrogen and phosphorus fertilizer for exploiting the yield potential and seed quality of French bean.

\section{Materials and Methods}

The experiment was conducted at Agronomy research field of Bangladesh Agricultural Research Institute (BARI), Gazipur, Bangladesh during November to April during 2010-11 and 2011-12. The experiment site was located Chhiata Series under Agro-Ecological Zone28 (AEZ-28) of $23^{\circ} 59^{\prime} \mathrm{N}$ and $90^{\circ} 24^{\prime} \mathrm{E}$. The rainfall during the experimental period was 42.0 $\mathrm{mm}$ in the first year and $189 \mathrm{~mm}$ in the second year. The soil of the experimental field was loamy in texture, low in organic matter (1.27\%), acidic in nature with $\mathrm{pH}(6.1)$ and contained very low amount of total nitrogen $(0.067 \%)$, phosphorus $(9.6 \%)$, sulphur $(12 \%)$, zinc (2 meq $\left.100 \mathrm{~g}^{-1}\right)$ and medium amount of potassium $\left(0.18 \mathrm{meq} 100 \mathrm{~g}^{-1}\right)$. The experiment was laid out in a randomized complete block design (RCBD) with three replications. The unit plot size was $4.8 \mathrm{~m} \times 3.0 \mathrm{~m}$. There were ten treatment combinations such as $\mathrm{N}_{0} \mathrm{P}_{0}, \mathrm{~N}_{0} \mathrm{P}_{44}, \mathrm{~N}_{50} \mathrm{P}_{44}$, $\mathrm{N}_{100} \mathrm{P}_{44}, \mathrm{~N}_{150} \mathrm{P}_{44}, \mathrm{~N}_{200} \mathrm{P}_{44}, \mathrm{~N}_{150} \mathrm{P}_{0}, \mathrm{~N}_{150} \mathrm{P}_{22}, \mathrm{~N}_{150} \mathrm{P}_{33}$ and $\mathrm{N}_{150} \mathrm{P}_{55}$. The source of $\mathrm{N}$ was urea and that of $\mathrm{P}$ was triple super phosphate. Other fertilizers were muriate of potash, gypsum and zinc sulphate, respectively. The total amount of TSP, muriate of potash, gypsum, zinc sulphate and $50 \%$ of urea were mixed with the soil during final land preparation and the rest urea was top dressed at 35 days after sowing (DAS). The seeds of french bean var. BARI Jharsheem-1 were sown on 25 November, 2010 and 2011, respectively. Seeds were treated with vitavax and sown continuously in $30 \mathrm{~cm}$ apart with plant distance $15 \mathrm{~cm}$. Weeding was done at 25 and 40 DAS. For uniform germination, a light irrigation was given by sprinkler method after sowing of seeds. Three irrigations were given at 25, 40 and 60 DAS. The yield component data were collected from 10 randomly selected plants prior to harvest from each plot. At harvest, the yield data was recorded plot wise and seeds were separated from the pods manually. The standard germination test was conducted following ISTA, 1996 rules. Seed vigour index was calculated by multiplying percent and seedling length. The protein content was calculated by multiplying the nitrogen content (\%) in seeds by 6.25. Data on all the parameters were analyzed statistically with the help of a computer package programme MSTAT -C and means were separated using DMRT.

\section{Results and Discussion}

\section{Yield and yield contributing characters}

The effects of $\mathrm{N}$ and $\mathrm{P}$ fertilizer application on yield and yield contributing characters of French bean in both the years (Table 1). Plant receiving more nitrogen prolonged duration to complete vegetative growth, which resulted longer time of flowering, as similar to Kaisar et al. (2007). The number of flowers plant ${ }^{-1}$ and pods plant ${ }^{-1}$ significantly increased with the increasing levels of $\mathrm{N}$. Plants treated with $200 \mathrm{~kg} \mathrm{~N} \mathrm{ha}^{-1}$ produced maximum number of flowers plant ${ }^{-1}$ followed by $150 \mathrm{~kg} \mathrm{~N}^{-1}$. Plants grown in $\mathrm{P}$ treated plots recorded significantly higher number of flowers plant ${ }^{-1}$ over control. Plants treated with $150 \mathrm{~kg} \mathrm{~N} \mathrm{ha}^{-1}$ produced maximum number of pods plant ${ }^{-1}$ which was statistically similar to $100 \mathrm{~kg} \mathrm{~N}$. Number of pods plant ${ }^{-1}$ increased due to sufficient supply of $\mathrm{N}$ for better growth of plant which might have led to higher photosynthesis and the development of higher number of pod bearing branches (Reddy et al., 2010; Prajapati et al., 2003). Percentage of abscission was slightly reduced by the application of $\mathrm{N}$ and $\mathrm{P}$ but the variations were not consistent with the level of $N$ and $P$ application in both the years (Table 1). Saha (2003) reported that plants supplied with adequate mineral $\mathrm{N}$ had a greater flower number but less pod set. 
Influence of Nitrogen and Phosphorus on Yield and Seed Quality of French Bean

The maximum seed size was observed in the plants grown with $150 \mathrm{~kg} \mathrm{~N}^{-1}$ which was statistically similar to 100 and $200 \mathrm{~kg} \mathrm{~N} \mathrm{ha}^{-1}$. Application of $44 \mathrm{~kg} \mathrm{P}$ gave the highest $100-$ seed weight which was at par with that of 22 and $55 \mathrm{~kg} \mathrm{P}^{-1}$ while smallest seeds from control plot. Averaged over the years significantly the highest seed yield was recorded in 150 $\mathrm{kg} \mathrm{N}$ and $44 \mathrm{P} \mathrm{kg} \mathrm{ha}^{-1}$ due to higher number of pods plant ${ }^{-1}$ and 100 -seed weight. The increase in yield might be due to increased availability of nitrogen and phosphorus, causing accelerated photosynthetic rate leading to more production of carbohydrates and improvement in growth and yield attributes. These results agree with the findings of Singh, 2000; and Reddy et al., 2010. Further increase of $\mathrm{N}$ and $\mathrm{P}$ fertilizers tended to decrease the seed yield There was positive linear relationship between pods plant ${ }^{-1}$ and seed yield (Fig. 1 and 2) indicating that 97 and $96 \%$ of total variation in seed yield of french bean could be explained by the linear function in pods plant ${ }^{-1}$ in both the years. Application of $\mathrm{N}$ fertilizer generally increased seed yield over $\mathrm{N}$ control but the yield response was not linear. Likewise increase in seed yield was observed up to $44 \mathrm{P} \mathrm{kg} \mathrm{ha}^{-1}$ and further increment seed yield was not increased due to the over growth of the plants. From the regression analysis it is observed that seed yield was related with the $N$ and $P$ levels following a quadratic relationship (Fig. 3 and 4) averaged over years. From the quadratic regression, $Y=-0.026 \mathrm{~N}^{2}$ $+9.33 \mathrm{~N}+684.7$, it is estimated that $178 \mathrm{~kg} \mathrm{~N}^{-1}$ is optimum dose for getting maximum seed yield of French bean. Srinivas and Naik (1990) reported optimum dose to be $125.6 \mathrm{~kg}$ $\mathrm{ha}^{-1}$ for French bean production while nitrogen was applied up to $160 \mathrm{~kg} \mathrm{ha}^{-1}$ in their field trial. The response of seed yield to phosphorus was quadratic in nature and from the regression equation, $Y=-0.141 \mathrm{P}^{2}+13.81 \mathrm{P}+1356$, the estimated optimum levels for getting maximum seed yield was $48.97 \mathrm{~kg} \mathrm{P} \mathrm{ha}^{-1}$. Seed yield was positively correlated with growth parameters and yield contributing characters viz., total dry matter production plant ${ }^{-1}$ at harvest $(0.953)$, number of pods plant ${ }^{-1}(0.986)$ and 100 -seed weight $(0.981)$.

Table 1. Seed yield and yield components of French bean as affected by levels of nitrogen and phosphorus fertilizer during 2010-11 and 2011-12

\begin{tabular}{l|c|c|c|c|c|c|cc}
\hline Treatments & \multicolumn{2}{|c|}{$\begin{array}{c}\text { Flowers plant } \\
\text { (no.) }\end{array}$} & \multicolumn{2}{c|}{ Pod plant ${ }^{-1}$ (no.) } & \multicolumn{2}{c|}{$\begin{array}{c}\text { 100-seed weight } \\
\text { (g) }\end{array}$} & \multicolumn{2}{c}{$\begin{array}{c}\text { Seed yield } \\
\left(\mathrm{kg} \mathrm{ha}^{-1}\right)\end{array}$} \\
\cline { 2 - 10 } & $2010-11$ & $2011-12$ & $2010-11$ & $2011-12$ & $2010-11$ & $2011-12$ & $2010-11$ & $2011-12$ \\
\hline $\mathrm{N}_{0} \mathrm{P}_{0}$ & $24.67 \mathrm{e}$ & $26.67 \mathrm{f}$ & $4.59 \mathrm{e}$ & $4.72 \mathrm{e}$ & $18.74 \mathrm{c}$ & $17.93 \mathrm{~d}$ & $682.16 \mathrm{f}$ & $673.02 \mathrm{e}$ \\
$\mathrm{N}_{0} \mathrm{P}_{44}$ & $27.67 \mathrm{e}$ & $32.00 \mathrm{~d}-\mathrm{f}$ & $5.17 \mathrm{de}$ & $5.13 \mathrm{e}$ & $19.17 \mathrm{c}$ & $19.29 \mathrm{~cd}$ & $750.12 \mathrm{ef}$ & $723.58 \mathrm{e}$ \\
$\mathrm{N}_{50} \mathrm{P}_{44}$ & $34.17 \mathrm{~d}$ & $35.33 \mathrm{c}-\mathrm{e}$ & $6.33 \mathrm{c}-\mathrm{e}$ & $5.82 \mathrm{de}$ & $21.15 \mathrm{~b}$ & $20.51 \mathrm{bc}$ & $956.79 \mathrm{de}$ & $981.98 \mathrm{~d}$ \\
$\mathrm{~N}_{100} \mathrm{P}_{44}$ & $38.17 \mathrm{bc}$ & $41.00 \mathrm{bc}$ & $8.08 \mathrm{a}-\mathrm{c}$ & $7.87 \mathrm{a}-\mathrm{c}$ & $23.06 \mathrm{a}$ & $22.73 \mathrm{ab}$ & $1375.12 \mathrm{a}-\mathrm{c}$ & $1413.15 \mathrm{a}-\mathrm{c}$ \\
$\mathrm{N}_{150} \mathrm{P}_{44}$ & $41.33 \mathrm{ab}$ & $45.03 \mathrm{ab}$ & $9.28 \mathrm{a}$ & $9.62 \mathrm{a}$ & $23.38 \mathrm{a}$ & $23.14 \mathrm{a}$ & $1543.33 \mathrm{a}$ & $1583.33 \mathrm{a}$ \\
$\mathrm{N}_{200} \mathrm{P}_{44}$ & $44.33 \mathrm{a}$ & $50.00 \mathrm{a}$ & $9.07 \mathrm{a}$ & $9.23 \mathrm{ab}$ & $21.83 \mathrm{ab}$ & $22.13 \mathrm{ab}$ & $1451.67 \mathrm{ab}$ & $1479.63 \mathrm{ab}$ \\
$\mathrm{N}_{150} \mathrm{P}_{0}$ & $25.67 \mathrm{e}$ & $30.43 \mathrm{ef}$ & $6.68 \mathrm{~b}-\mathrm{d}$ & $7.06 \mathrm{~cd}$ & $21.12 \mathrm{~b}$ & $20.87 \mathrm{a}-\mathrm{c}$ & $1158.27 \mathrm{~cd}$ & $1206.36 \mathrm{c}$ \\
$\mathrm{N}_{150} \mathrm{P}_{22}$ & $35.67 \mathrm{~cd}$ & $38.40 \mathrm{~b}-\mathrm{d}$ & $7.53 \mathrm{a}-\mathrm{c}$ & $7.62 \mathrm{bc}$ & $22.41 \mathrm{ab}$ & $22.07 \mathrm{ab}$ & $1259.75 \mathrm{bc}$ & $1314.38 \mathrm{bc}$ \\
$\mathrm{N}_{150} \mathrm{P}_{33}$ & $38.33 \mathrm{bc}$ & $41.33 \mathrm{bc}$ & $8.50 \mathrm{ab}$ & $8.71 \mathrm{a}-\mathrm{c}$ & $22.76 \mathrm{a}$ & $22.20 \mathrm{ab}$ & $1495.00 \mathrm{ab}$ & $1536.90 \mathrm{ab}$ \\
$\mathrm{N}_{150} \mathrm{P}_{55}$ & $41.00 \mathrm{ab}$ & $43.87 \mathrm{ab}$ & $8.35 \mathrm{ab}$ & $8.62 \mathrm{a}-\mathrm{c}$ & $22.16 \mathrm{ab}$ & $21.83 \mathrm{ab}$ & $1420.00 \mathrm{a}-\mathrm{c}$ & $1460.00 \mathrm{ab}$ \\
\hline $\mathrm{CV}(\%)$ & 4.65 & 6.83 & 10.13 & 9.31 & 2.89 & 4.51 & 8.88 & 7.25 \\
\hline
\end{tabular}

$\mathrm{NS}=$ Not significant, $\mathrm{CV}=\mathrm{Co}$ efficient of variation.

In a column, figures having common letter(s) do not differ significantly at $1 \%$ level by DMRT 
4

Kakon et al.

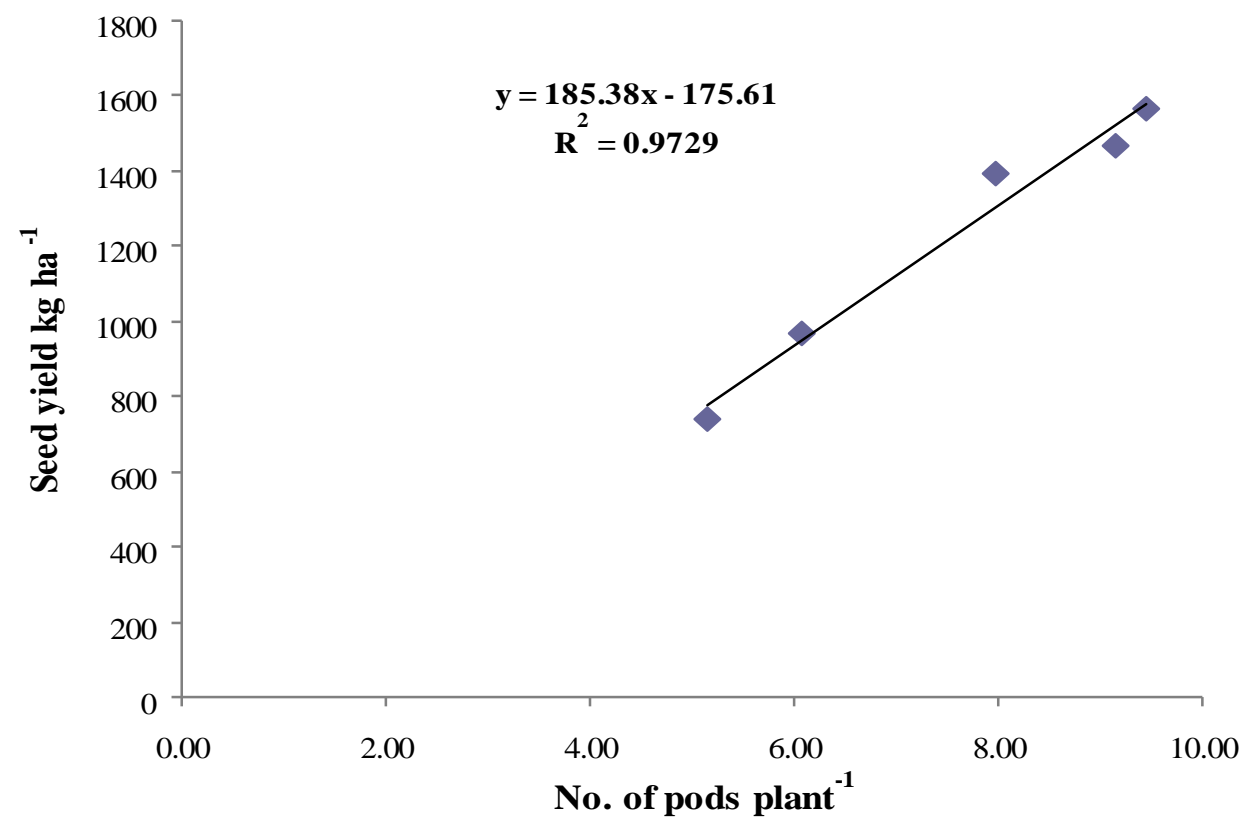

Fig.1 Relationship between pods plant ${ }^{-1}$ (no.) and seed yield as affected by nitrogen level ave raged over years.

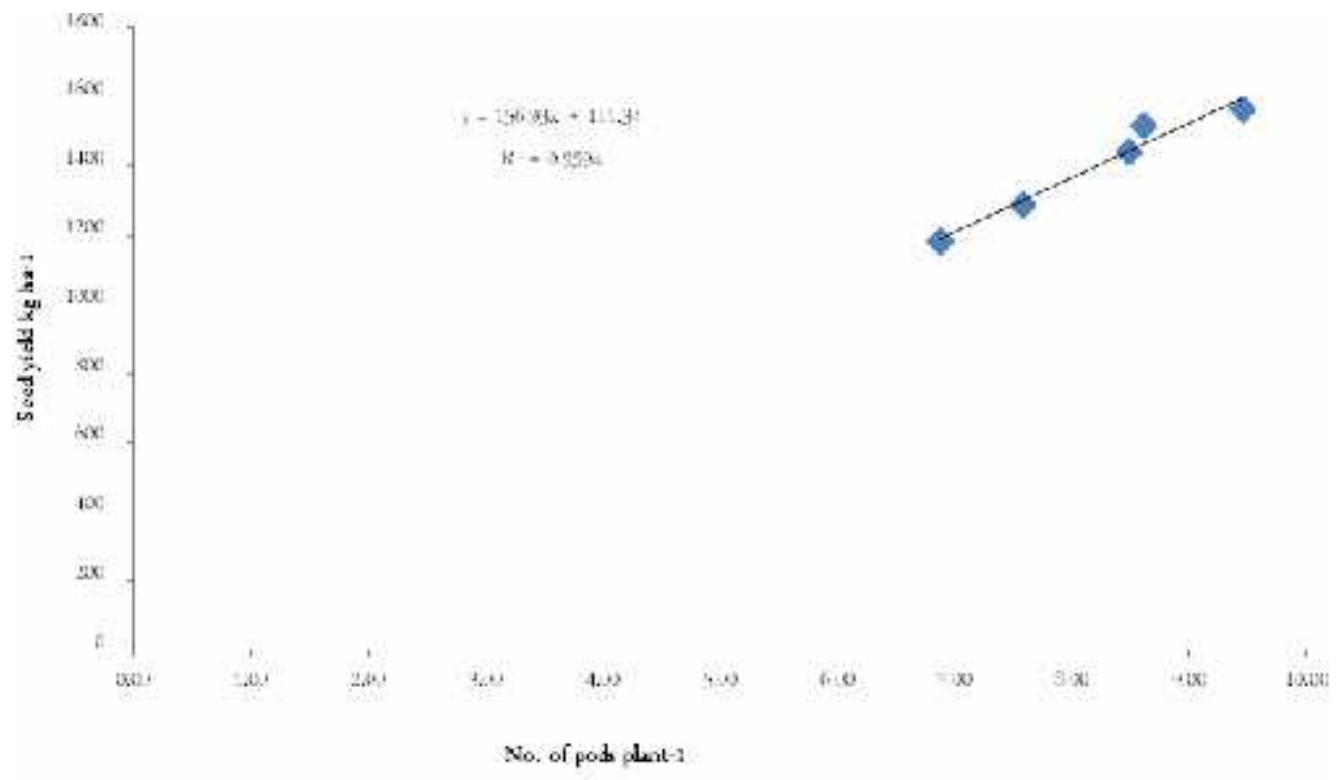

Fig. 2. Relasuondip betwera pudy plant (no.) and seed yield as afectad by phosphonus leved (averayod aver years) 
5

Influence of Nitrogen and Phosphorus on Yield and Seed Quality of French Bean

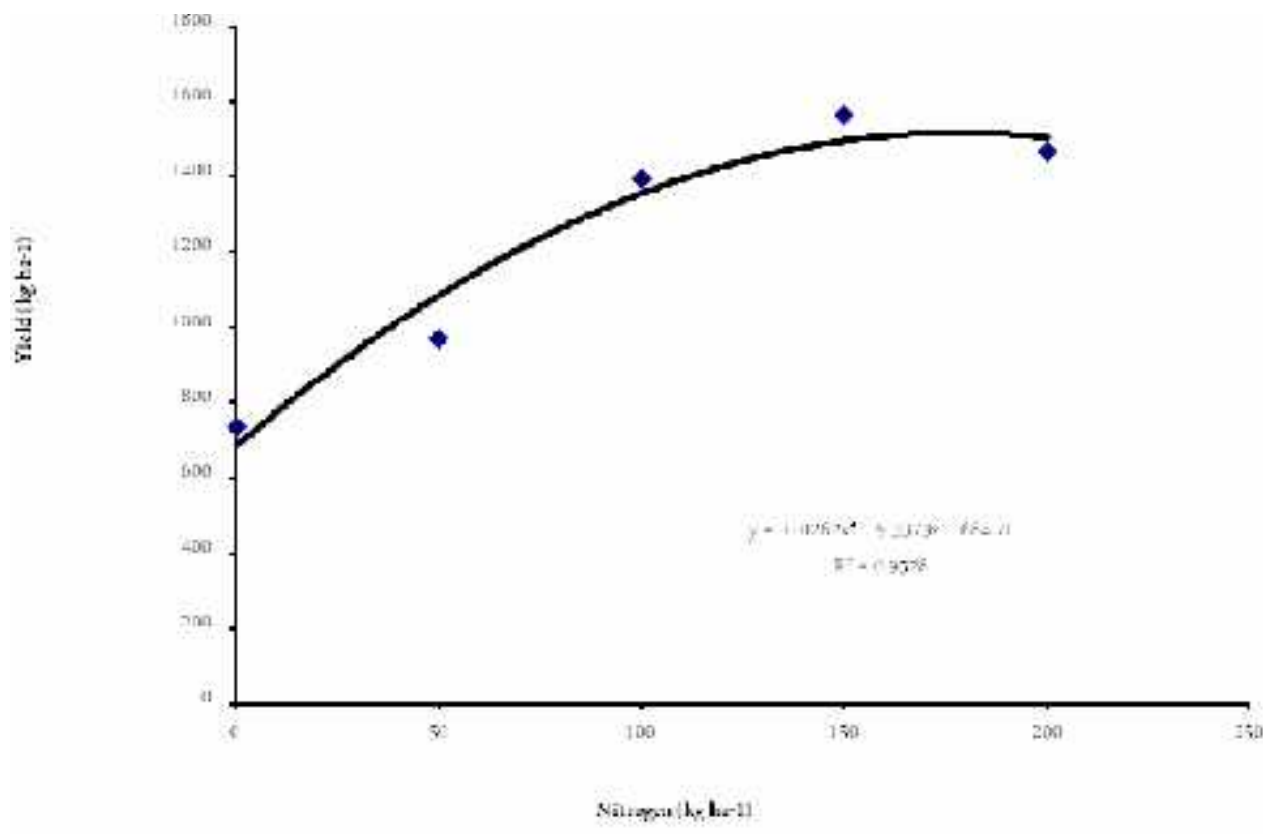

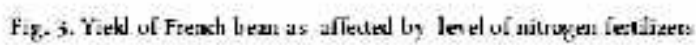
(averaged over years)

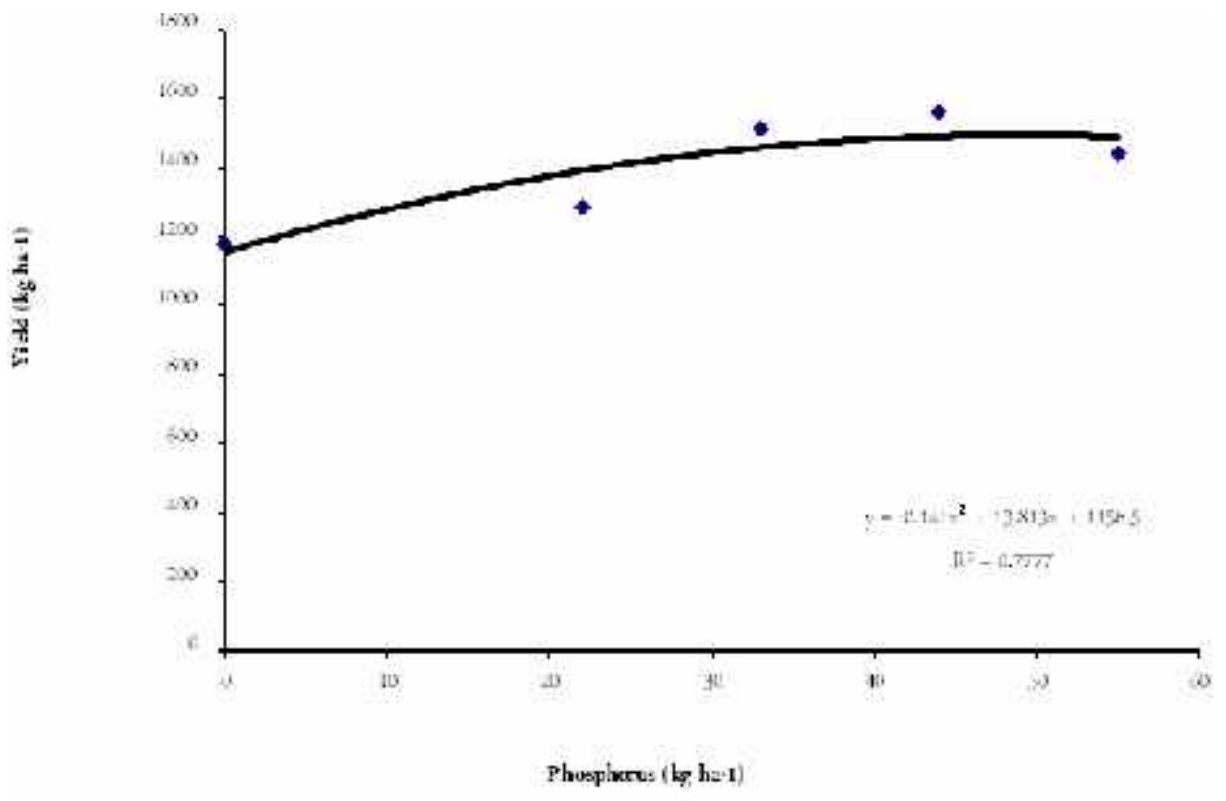

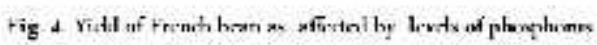
tedilises [averaged ores yeas] 
Kakon et al.

\section{Seed quality}

The highest germination was obtained in plants which received $N_{150} P_{44} \mathrm{~kg}$ ha ${ }^{-1}$ while the lowest seed germination from plants that received no fertilizer. Application of $\mathrm{N}$ rates exerted a continuous significant increase in the percent germination up to $150 \mathrm{~kg} \mathrm{~N}^{-1}$ over 50 and $100 \mathrm{~kg} \mathrm{~N} \mathrm{ha}^{-1}$. Beyond this decreased germination (\%) received $200 \mathrm{~N} \mathrm{~kg} \mathrm{ha}^{-1}$. Phosphorus exerted a significant influence on seed germination up to $22 \mathrm{~kg} \mathrm{ha}^{-1}$ over control (Table 2). Significant increase in seed quality parameters was due to increase in 100 - seed weight which in turn might have supplied adequate food reserves during germination and resulting in exhibiting of higher seedling vigour.

\section{Vigour index}

The best quality in respect of seedling vigour index was recorded with $\mathrm{t} 200 \mathrm{~N}$ but at par to $150 \mathrm{~kg} \mathrm{~N} \mathrm{ha}^{-1}$ while control plot produced the lowest seedling vigour index. Similar results were reported by Saha (2003). The maximum seedling vigour indexes were recorded from $55 \mathrm{~kg} \mathrm{P} \mathrm{ha}^{-1}$ and it was at par with that of $22 \mathrm{~kg}$ and $33 \mathrm{~kg} \mathrm{P} \mathrm{ha}^{-1}$.

Table 2. Effects of different levels of nitrogen and phosphorus fertilizers on seed quality of French bean during 2010-11 and 2011-12

\begin{tabular}{l|c|c|c|c|c|c}
\hline \multirow{2}{*}{\begin{tabular}{c}
$N$ \\
\multicolumn{1}{c}{ levels }
\end{tabular}} & \multicolumn{2}{|c|}{ Germination (\%) } & \multicolumn{2}{c|}{ Vigour Index } & \multicolumn{2}{c}{ Protein (\%) } \\
\cline { 2 - 7 } & $2010-11$ & $2011-12$ & $2010-11$ & $2011-12$ & $2010-11$ & $2011-12$ \\
\hline $\mathrm{N}_{0} \mathrm{P}_{0}$ & $88.0 \mathrm{~b}$ & $81.00 \mathrm{e}$ & $2192.63 \mathrm{e}$ & $1872.00 \mathrm{~d}$ & $20.77 \mathrm{e}$ & $21.02 \mathrm{~d}$ \\
$\mathrm{~N}_{0} \mathrm{P}_{44}$ & $90.5 \mathrm{ab}$ & $84.33 \mathrm{de}$ & $2364.52 \mathrm{c}-\mathrm{e}$ & $2003.80 \mathrm{~cd}$ & $21.25 \mathrm{de}$ & $21.54 \mathrm{~cd}$ \\
$\mathrm{~N}_{50} \mathrm{P}_{44}$ & $92.5 \mathrm{ab}$ & $89.67 \mathrm{~b}-\mathrm{d}$ & $2572.85 \mathrm{~b}-\mathrm{d}$ & $2192.13 \mathrm{bc}$ & $22.08 \mathrm{~cd}$ & $22.40 \mathrm{~b}-\mathrm{d}$ \\
$\mathrm{N}_{100} \mathrm{P}_{44}$ & $95.17 \mathrm{a}$ & $92.33 \mathrm{a}-\mathrm{c}$ & $2785.92 \mathrm{~b}$ & $2310.23 \mathrm{~b}$ & $22.94 \mathrm{a}-\mathrm{c}$ & $23.17 \mathrm{a}-\mathrm{c}$ \\
$\mathrm{N}_{150} \mathrm{P}_{44}$ & $95.5 \mathrm{a}$ & $96.58 \mathrm{a}$ & $3120.02 \mathrm{a}$ & $2678.27 \mathrm{a}$ & $23.65 \mathrm{a}$ & $23.85 \mathrm{ab}$ \\
$\mathrm{N}_{200} \mathrm{P}_{44}$ & $93.2 \mathrm{ab}$ & $95.33 \mathrm{ab}$ & $3150.53 \mathrm{a}$ & $2860.27 \mathrm{a}$ & $23.96 \mathrm{a}$ & $24.04 \mathrm{a}$ \\
$\mathrm{N}_{150} \mathrm{P}_{0}$ & $88.83 \mathrm{~b}$ & $86.67 \mathrm{c}-\mathrm{e}$ & $2256.73 \mathrm{de}$ & $2061.77 \mathrm{~b}-\mathrm{d}$ & $22.71 \mathrm{bc}$ & $22.75 \mathrm{a}-\mathrm{c}$ \\
$\mathrm{N}_{150} \mathrm{P}_{22}$ & $90.33 \mathrm{ab}$ & $90.00 \mathrm{~b}-\mathrm{d}$ & $2527.55 \mathrm{~b}-\mathrm{d}$ & $2168.10 \mathrm{bc}$ & $22.83 \mathrm{a}-\mathrm{c}$ & $23.23 \mathrm{a}-\mathrm{c}$ \\
$\mathrm{N}_{150} \mathrm{P}_{33}$ & $92.5 \mathrm{ab}$ & $90.67 \mathrm{a}-\mathrm{c}$ & $2636.58 \mathrm{bc}$ & $2321.27 \mathrm{~b}$ & $23.19 \mathrm{ab}$ & $23.38 \mathrm{ab}$ \\
$\mathrm{N}_{150} \mathrm{P}_{55}$ & $91.27 \mathrm{ab}$ & $94.8 \mathrm{ab}$ & $3125.57 \mathrm{a}$ & $2739.25 \mathrm{a}$ & $22.96 \mathrm{ab}$ & $23.56 \mathrm{a}-\mathrm{c}$ \\
\hline $\mathrm{CV}(\%)$ & 2.21 & 2.73 & 5.12 & 5.28 & 1.59 & 2.92 \\
\hline
\end{tabular}

$\mathrm{CV}=$ Co efficient of variation.

In a column, figures having common letter (s) do not differ significantly at $1 \%$ level by DMRT

\section{Protein content of seed}

Significantly higher protein content of seed was gained by applying $200 \mathrm{~kg} \mathrm{~N}$ which was statistical similar to $150 \mathrm{~kg} \mathrm{ha}^{-1} \mathrm{~N}$. These results are in agreement with (Singh et al., 2001) in soybean. However, when the plants grown without added $\mathrm{N}$ and $\mathrm{P}$ fertilizer produced the lowest protein content in seeds. Protein content significantly increased with increasing $P$ fertilization 6.90 and $3.74 \%$ higher protein content was recorded with $44 \mathrm{~kg} \mathrm{P}$ compared to 22 and $33 \mathrm{~kg} \mathrm{Pha}^{-1}$, respectively. This might also be due to enhanced rate of bacterial nodulation (Ssali and Keya, 1986) and nitrogen fixation.

\section{Conclusion}

Two years result revealed that the application of $\mathrm{N}$ and $\mathrm{P}$ fertilizer up to150 and $44 \mathrm{~kg} \mathrm{ha}{ }^{1}$ exerted significantly positive effects on French bean in terms of seed yield and quality in Joydebpur area.

\section{References}


Influence of Nitrogen and Phosphorus on Yield and Seed Quality of French Bean

Ali, M and S. Lal. 1992 Technology for Rajmash Cultivation in Plain. Indian Farming 42:2526

ISTA. 1996. International rules for seed testing. Seed sci. and Technol. 24 (Supppl.) 335 $337 \mathrm{pp}$.

Kaisar, M. O., S. Zaman, A. K. M. S. Hoque, S. M. L. Rahman and M. M. Zaman. 2007. Effect of nitrogen and phosphorus on growth, yield and profitability of French bean. Bangadesh J. Prod. Sci. Technol. 5(2): 373-376.

Kushwaha, B. L. 1994. Response of French bean (Phaseolus vulgaris L.) to nitrogen application in north Indian plains. Indian J. Agron. 39: 34-37.

Mullins, G. L., B. F. Hajek and C.W. Wood. 1996. Phosphorus in agriculture. Bull. NO.2. Dept. of Agronomy and Soils, Auburn, USA.

Padrit, J., J. G. Hampton., M. J. Hill and B. R. Watkin. 1996. The effect of nitrogen and

phosphorus supply to the mother plant on seed vigour in garden pea (Pisum sativum L.) Cv. Pania. J. Appl. Seed Prod. 14: 41-45.

Pierce,L. C. 1987. Legumes In: Vegetable: Characters, Production and Marketing. John Wiley and Sons, New York. pp 561-567.

Prajapati, M. P. and B. M. Patel. 2003. Effects of integrated weed management and nitrogen levels of weed and productivity of French bean under North Gujarat conditions. Legume Res. 26(2) 79-84.

Rao, B. R., S. P. Singh and E.V.S. Rao. 1983. Nitrogen, potassium and phosphorus studies in pyrethrum (Chrysanthemum cinerariifolium L.). J. Agric. Sci., 100: 509-511.

Rashid, M. M. 1999. Sabji Biggan. In Bangla. $2^{\text {nd }}$ Ed., Rashid Publishing House, Dhaka. pp. 396 -399.

Reddy, M., Malla. Padmaja, B. Reddy and R. Ram. 2010. Response of French bean to irrigation schedules and nitrogen levels in Talangana region of Andhra Pradesh. J. Food Legumes. 23(1): 38-40.

Saha, R. R. 2003. Physiological aspects of yield and seed quality of mungbean (Vigna radiata (L) Wilczek Ph.D. Thesis, Department of Agronomy, Bangabandhu Sheikh Mujibur Rahman Agricultural University, Salna, Gazipur.

Singh, R.V. 2000. Response of French bean (Phaseolus vulgaries L.) to plant, spacing and nitrogen, phosphorus fertilization. Indian J. Hort. 57: 338-341.

Srinivas, K. and L. B. Naik 1990. Growth, yield and nitrogen uptake in vegetable French bean (Phaseolus vulgaris L.) as influenced by nitrogen and phosphorus fertilization. Haryana J. Hort. Sci. 19 (1-2): 160-167.

Ssali, H. and S. O. Keya. 1986. The effect of phosphorus and nitrogen fertilizer level on nodulation, growth and dinitrogen fixation of three bean cultivars. Trop. Agric. 63:105-109.

Tanaka, A., J. Yamaguchi, S. Miura and H. Tamaru.1984. Comparison of fertilizer nitrogen efficiency among field crops. Soil Sci. Plant Nutr. 30 (2): 199-208.

Veeresh, N. K. 2003. Response of French bean (Phaseolus vulgaris L.) to fertilizer levels in Northern Transitional Zone of Karnataka. M.Sc. (Agri.) Thesis, University of Agricultural Science, Dharwad. 
Kakon et al.

Vinod, R. P., S. Acharya, S. Ganesh, V. Rajput, P . Acharya and G. Singh. 1999. Effect of dates of sowing and graded doses of nitrogen on growth and yield of French bean cv. Contender in eastern U. P. Orissa J. Hort. 27 (2): 39-42.

Wolfe, D. W., D.W. Henderson, T. C. Hsiao and A. Alvino. 1988. Interactive water and nitrogen effects of senescence of maize II. Photosynthesis and longevity of individual leaves. Agron. J. 80: 865-870. 